\title{
From Teachers' Views to Explore the Implementation of Energy Education in Taiwan's Elementary Schools
}

\author{
Mei-Ching Chen ${ }^{1}$, Chin-Cheng Chou ${ }^{2}$, Chao-Ti Hsiung ${ }^{3}$ \\ Department of Science Education, National Taipei University of Education, Taiwan 1,2,3 \\ maygood@gmail.com ${ }^{1}$, ccchou62@gmail.com², hsiungct@gmail.com ${ }^{3}$
}

Received: April $8^{\text {th }}, 2020$. Revised: May $14^{\text {th }}, 2020$. Accepted: May $20^{\text {th }}, 2020$

\author{
Keywords : \\ Energy Attitude; Energy \\ Awareness; Energy Behavior; \\ Energy Education
}

\begin{abstract}
This study intended to explore the implementation of promoting "energy education" in Taiwan's elementary schools. The research adopted a questionnaire (Likert fivepoint scale) from teachers' view in three dimensions to construct examination. The 45 participants come from 10 different primary schools distributed across Taiwan, which participate in energy education program in the second period (2015-2017). The data was analyzed by ANOVA, mean and standard deviations of the viewpoints of the participants in the energy education learning achievement of the primary schools. The first findings in this research is, the program of energy education was most effective in "energy attitude" $(M=4.282, S D=0.814)$, followed by "energy awareness" $(M=4.049, S D=0.720)$ and "energy behavior" $(M=3.983, S D=0.875)$. It shows that students have positive energy attitude, but they were relatively weak at energy saving behavior. Secondly, there is statistically significant difference in overall students learning performance with urban areas are higher than rural areas. Finally, it is suggested that in addition to strengthen energy attitudes and energy awareness, we should encourage students to take action in save energy in their daily life. Furthermore, we should invest more resources to rural areas to balance the students' performances between urban and rural areas.
\end{abstract}

\section{INTRODUCTION}

Energy is the "underlying currency that governs everything humans do with each other and supports the interactions between humans and natural environment." To make energy sustainable, educating citizens to have the correct energy attitude, energy awareness, and energy behavior is a global major issue in this century [1]. However, as a result of over-reliance on fossil energy, we face a crisis of energy depletion and environmental degradation in the $21^{\text {st }}$ century. Therefore, everyone in the global village is urgently needed to participate in improving the existing energy efficiency, developing new energy, implementing energy conservation and carbon reduction [2-3]. Kok, Lo, Peters and Ruiter also mentioned that more 
From Teachers' Views to Explore the Implementation of Energy Education in Taiwan's Elementary Schools Mei-Ching Chen, Chin-Cheng Chou, Chao-Ti Hsiung

and more scholarly researches suggest that through changing people's behavior to reduce people's energy consumption behavior [4].

From 2005 to 2014, the UNESCO promoted the "United Nations Decade of Education for Sustainable Development program" to spread the idea of sustainable development. This program emphasized the importance of education and citizen literacy. The best practice for promoting citizen understanding of sustainable development is to increase the awareness, understanding of problem-solving, discussion, and problem-solving behaviors [5].

Taiwan has a high-quality performance on the primary and secondary school science education, and our government hopes to further improve the quality of energy education. From 1999 to 2015, Trends in International Mathematics and Science Study (TIMSS) was surveyed the fourth and eighth graders every four years. The ranking of scores showed that Taiwan students' performances can be described as "outstanding" [6-7]. The school strives to cultivate talents through education and actively implements the strategy of "sustainable development" of energy. In 2009, Taiwan Government initiated the National Energy Program and declared 2010 as "the first year of energy saving and carbon reduction". In 2011, the Ministry of Education (MOE) established the Energy-Based National Science and Technology Talents Cultivation Program (EBNSTTCP) and supported organizations, including teaching alliance, teacher training program and energy-education centers. Figure 1 presents the complete Technology Program Framework in Taiwan, which demonstrates the importance of cultivating energy and technology personnel. In figure 1, we could find the hierarchy from central to local program that is "sustainable green environment", "improve student competencies in energy and carbon reduction and disaster prevention" and "Energy conservation and environmental sustainability".
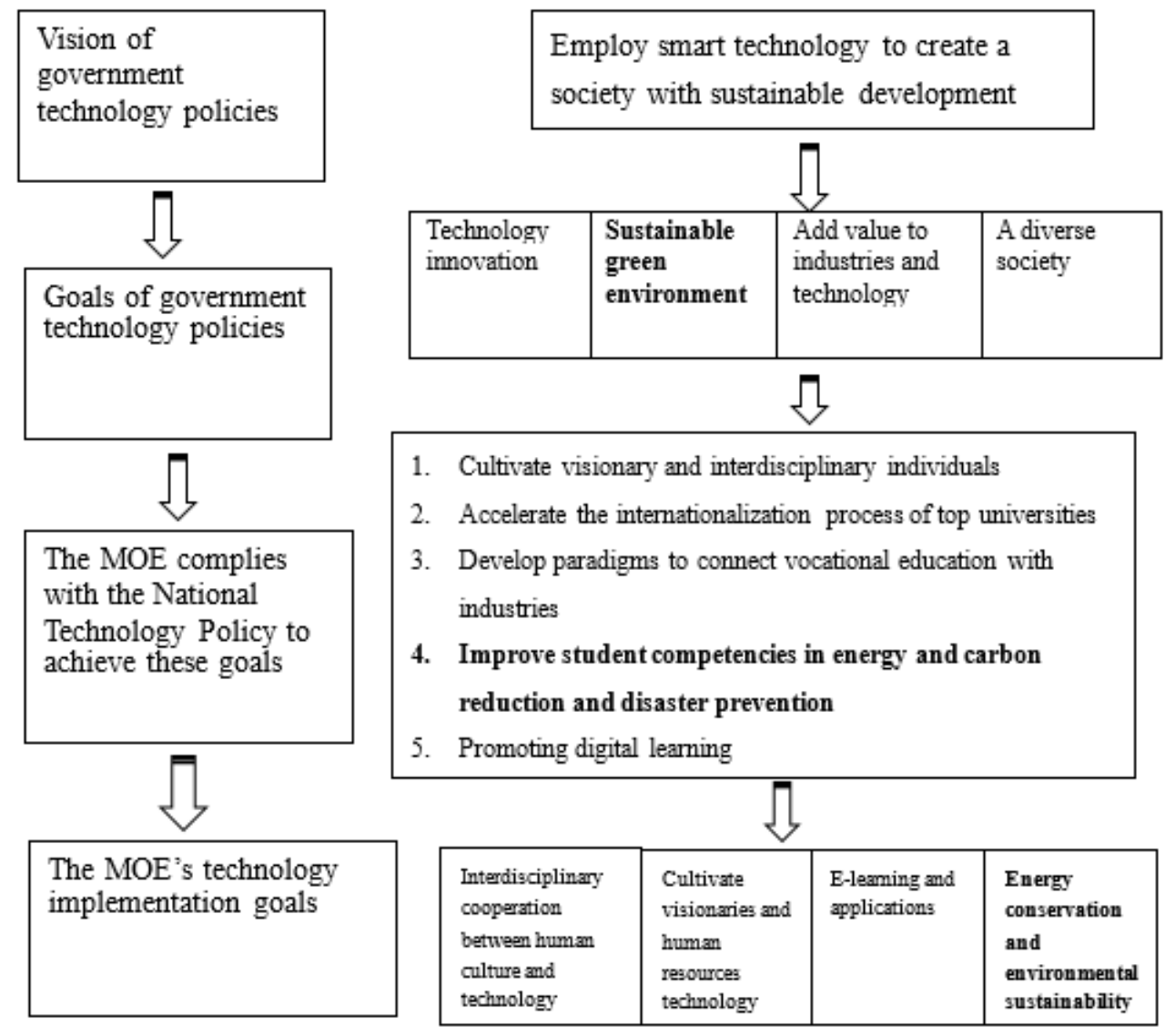

Fig 1. Two Technology Program Framework in Taiwan 
European energy policies and energy technology committees have indicated that European countries greatly value energy technology education, as well as that energy technology education is crucial to changing energy usage habits [5]. The socioscientific issues topics like environmental issues, sustainable development, energy choices have been introduced in French middle schools [8]. The United States Department of Energy (DOE) is responsible for national energy management. The US is the first country to implement energy education by initiating the National Energy Education Development Project in 1980. Because the project has been running for nearly 40 years, it has considerable influence on the energy education in US schools [4]. Thollander, Kimura, Wakabayashi, and Rohdin pointed that the energy efficiency plays an important role in meeting the challenge of power supply shortage after the great earthquake in Japan 2011 [9]. Renewable energy is the one focus in school education [7].

Zorpas, Voukkali, and Loizia stated that behaviors must be trained at a young age and perceptions must be altered before behavioral changes. This enables students to influence their family members and subsequently the society as a whole [10]. William and Argiri stated the importance of academia and schools in solving energy problems [11]. Teachers should teach and guide students to think about energy-related topics and then cultivate their energy knowledge, attitudes, and behaviors in order to fulfill their parts in society.

These efforts are consistent with the viewpoint of Prof. Debra C. Roberts , co-chair of Working Group III of the Intergovernmental Panel on Climate Change, who stated that individual energy education starts from one's basic needs [8]:

"You might say you don't have control of the use of land, but you do have control over what you want to have on your dining table...."

This indicated that teaching appropriate energy use concepts and habits to young children, making them to fulfill in their daily lives, is the key for schools to implement energy education. The effectiveness refers to an educated learner can still hold the key concept after a long period of time [6].

Therefore, this study explores the effectiveness of Taiwan's energy education from the perspective of teachers who joined the EBNSTTCP project. It was expected that the results will be used as a reference for various research institutions take action the implementation of energy education to increase students willingness in daily life.

In addition to exploring learning outcomes from energy awareness, energy attitudes and energy behavior, some studies also explore learning outcomes in different regions. Zorpas, Voukkali, \& Loizia mentioned that 617 respondents from both rural and urban areas filled in a questionnaire. The results indicate that students studying in urban areas are more aware of renewable energy in comparison to those students in rural areas. This study also highlights the importance of implementing renewable energy education as early as possible [12]. Another study of 459 urban and suburban elementary school students from Brazil and Portugal found that students in the suburbs had a more positive attitude towards nature protection, and that information provided online could raise students' awareness of environmental protection [10].

Some studies had found that the behavior attitude of primary school students is directly affected by the parents or social environment. In addition, behavior changes should start from an early age, awareness changing first, and encourage students to demonstrate in their daily life [12-13].

In order to understand whether the effectiveness of Taiwan's energy education implementation can achieve the same results as the previous literature research, we conducted this study. This study intended to explore the effectiveness of energy education implementation in Taiwan from the teacher's point of view. To explore the learning effectiveness of energy awareness, energy attitudes and energy behavior, and whether there are differences in learning outcomes between different areas. 
From Teachers' Views to Explore the Implementation of Energy Education in Taiwan's Elementary Schools Mei-Ching Chen, Chin-Cheng Chou, Chao-Ti Hsiung

\section{METHOD}

\section{Participants}

This study administered questionnaires to 45 school staff members, including principals, directors and teachers from 10 elementary schools who participated in the MOE Energy Technology Human Resources Development Program Phase II (2015-2017). Figure 2 displays the locations and codes of the schools that participated.

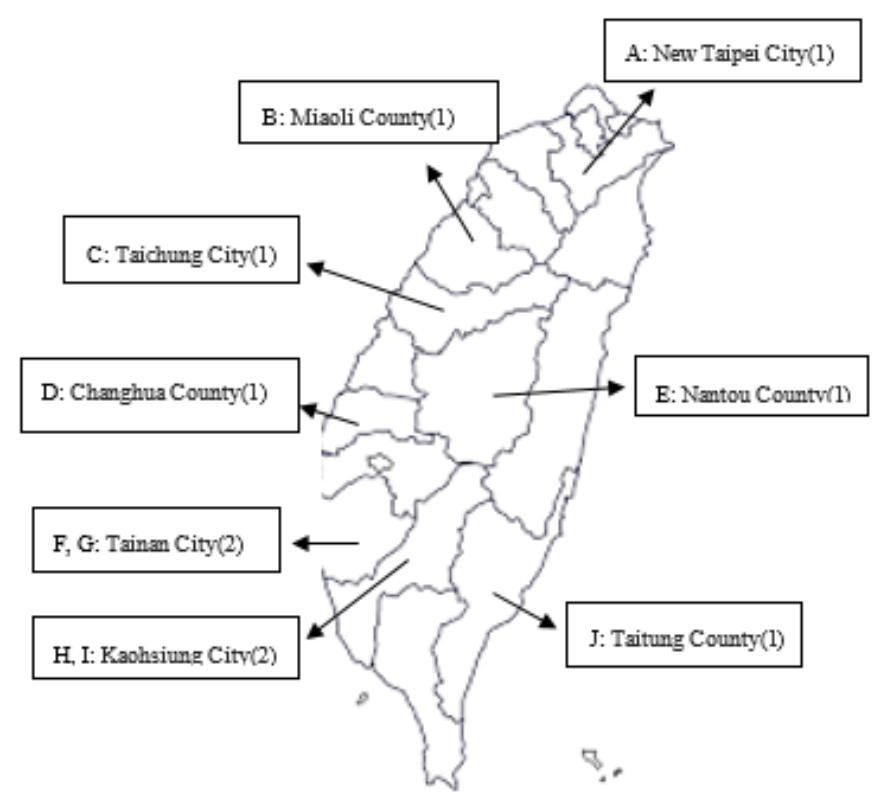

Fig 2. Location and codes of the schools that participated in promoting Ministry of Education (MOE) established the Energy-Based National Science and Technology Talents Cultivation Program (EBNSTTCP)

Research tools

This research adopted the questionnaire survey method. There are three dimensions in the learning performance scale, and with four items for each dimension. The questionnaire was presented in Chinese. Five science evaluated the validity of questionnaire. The Cronbach's $\alpha$-value of the questionnaire is 0.95 , which is higher than the critical value 0.70 [14], which indicates the questionnaire in this study has a high reliability.

Data processing and analysis

This study used SPSS 21.0 for Windows to analyze the questionnaire results. The mean (M) and standard deviation (SD) were calculated to analyze the participants' perceptions of effectiveness of promoting energy education in elementary schools. Analysis of variance (ANOVA) was conducted to analyses whether the schools have significant different performances in the promotional effectiveness dimensions.

\section{RESULTS AND DISCUSSIONS}

\section{Effectiveness of promoting energy education in elementary schools}

(a) Energy knowledge

This dimension consisted of four items. The mean scores of the items ranged between 3.800 and 4.200 . The highest mean score is item three $(\mathrm{M}=4.200, \mathrm{SD}=0.660)$. The item is that the energy education 
teaches students the uses and current use condition of new energy". Item one has the lowest M score (M $=3.800, \mathrm{SD}=0.726)$. The item is that energy education teaches students energy conversion concepts, including different energy conversion efficiencies and energy loss. Therefore, the main effect of energy education in elementary schools is improving students on understanding of the uses of new energy. The item one has the lowest mean because the energy conversion may be relatively abstract and difficult to understand for elementary school students. It needs practical examples in life, such as how solar energy is converted into electrical energy, so that students can understand the relationship between conversions.

\section{(b) Energy attitude}

This dimension comprises four items. The mean scores of the items ranged between 4.044 and 4.488 . The highest mean score is item one $(\mathrm{M}=4.488, \mathrm{SD}=0.588)$. The item is that energy education teaches students the importance of sustainable development. Item three has the lowest mean score $(\mathrm{M}=4.044$, $\mathrm{SD}=0.952$ ). The item is that energy education promotes students' willingness to set personal energy and carbon reduction goals. This implied that energy education teaches students the importance of sustainable development. And we should also strengthen students' willingness to set and meet their energy saving goals.

\section{(c) Energy behavior}

This dimension included four items. The mean scores of the items ranged between 3.777 and 4.111. The highest mean score is item one $(\mathrm{M}=4.111, \mathrm{SD}=0.858)$ The item is that energy education enables students to design energy and carbon reduction plans for their family or community. The item one has the lowest mean score $(\mathrm{M}=3.77, \mathrm{SD}=0.950)$. The item is that energy education promotes students seeking energy-related information and planning practical energy use strategies. This indicated that energy education encourages students to act in designing practical energy and carbon reduction plans for their family and community. The item one has the lowest mean, because the students' ability to collect energy issues are relatively weak. Teachers still gave too much lecture, and students had no opportunity to collect information.

Table 1. Results Analysis of the Promotional Effectiveness Section

\begin{tabular}{|c|c|c|c|c|}
\hline Dimension & Item & Mean & SD & Order \\
\hline \multirow{4}{*}{$\begin{array}{l}\text { Energy } \\
\text { knowledge }\end{array}$} & $\begin{array}{l}\text { 1. Energy education teaches students energy } \\
\text { conversion concepts, including different energy } \\
\text { conversion efficiencies and energy loss. }\end{array}$ & 3.800 & .726 & 4 \\
\hline & $\begin{array}{l}\text { 2. Energy education teaches students the current use } \\
\text { conditions and future development of renewable } \\
\text { and nonrenewable energy. }\end{array}$ & 4.044 & .638 & 3 \\
\hline & $\begin{array}{l}\text { 3. Energy education teaches students the uses and } \\
\text { current use condition of new energy. }\end{array}$ & 4.200 & .660 & 1 \\
\hline & $\begin{array}{l}\text { 4. Energy education teaches students the principles of } \\
\text { energy development (i.e., high efficiency and } \\
\text { value, low emissions, and reduced reliance on } \\
\text { imported energy). }\end{array}$ & 4.155 & .796 & 2 \\
\hline \multirow{4}{*}{$\begin{array}{l}\text { Energy } \\
\text { attitude }\end{array}$} & $\begin{array}{l}\text { 1. Energy education teaches students the importance } \\
\text { of sustainable development. }\end{array}$ & 4.488 & .588 & 1 \\
\hline & $\begin{array}{l}\text { 2. Energy education teaches students to actively } \\
\text { brainstorm the development of new energy } \\
\text { technology suitable for environmental } \\
\text { characteristics. }\end{array}$ & 4.355 & .712 & 2 \\
\hline & $\begin{array}{l}\text { 3. Energy education promotes students' willingness to } \\
\text { set personal energy and carbon reduction goals. }\end{array}$ & 4.044 & .952 & 4 \\
\hline & $\begin{array}{l}\text { Energy education promotes students actively } \\
\text { sharing energy reduction tips in everyday life. }\end{array}$ & 4.244 & .908 & 3 \\
\hline
\end{tabular}


From Teachers' Views to Explore the Implementation of Energy Education in Taiwan's Elementary Schools Mei-Ching Chen, Chin-Cheng Chou, Chao-Ti Hsiung

\begin{tabular}{|c|c|c|c|c|c|}
\hline \multirow{4}{*}{$\begin{array}{c}\text { Energy } \\
\text { behavior }\end{array}$} & 1. & $\begin{array}{l}\text { Energy education promotes students seeking } \\
\text { energy-related information and planning practical } \\
\text { energy use strategies. }\end{array}$ & 3.777 & .950 & 4 \\
\hline & 2. & $\begin{array}{l}\text { Energy education promotes students expressing } \\
\text { their social responsibilities and concern for } \\
\text { sustainable energy use through diverse methods, } \\
\text { including plays, discussions, and providing } \\
\text { explanations. }\end{array}$ & 4.044 & .851 & 2 \\
\hline & 3. & $\begin{array}{l}\text { Energy education enables students to participate in } \\
\text { energy management investigations, research, and } \\
\text { problem solving at school or home. }\end{array}$ & 4.000 & .825 & 3 \\
\hline & 4. & $\begin{array}{l}\text { Energy education enables students to design energy } \\
\text { and carbon reduction plans for their family or } \\
\text { community. }\end{array}$ & 4.111 & .858 & 1 \\
\hline
\end{tabular}

As shown in Table 2 the mean of effectiveness of promoting energy education in elementary schools was 4.104. The mean of the dimensions ranged between 3.983 and 4.282. Among the three dimensions, energy attitude $(\mathrm{M}=4.282, \mathrm{SD}=0.814)$ demonstrated as the greatest implementation effect. This indicated that students often expressed their viewpoints as well as evaluations, senses and actions in response to energy-related problems. Thereby they demonstrate greater awareness of energy awareness, energy-related topics, and civic responsibilities.

Table 2. Results Analysis of Promotional Effectiveness Dimensions

\begin{tabular}{cccccc}
\hline Dimension & $\begin{array}{c}\text { Item } \\
\text { number }\end{array}$ & N & M & SD & Order \\
\hline Energy knowledge & 4 & 45 & 4.049 & 0.720 & 2 \\
Energy attitude & 4 & 45 & 4.282 & 0.814 & 1 \\
Energy behavior & 4 & 45 & 3.983 & 0.875 & 3 \\
\hline Total performance & $\mathbf{1 2}$ & $\mathbf{4 5}$ & $\mathbf{4 . 1 0 4}$ & $\mathbf{0 . 8 1 4}$ & \\
\hline
\end{tabular}

Table 3 Displays the ANOVA analysis results. There were no statistically significant difference among three dimensions. The results indicated that energy education promotional effectiveness was similar across the three dimensions.

Table 3. ANOVA Analysis of the Promotional Effectiveness Results

\begin{tabular}{lcccccc}
\hline & $\begin{array}{c}\text { Sample } \\
\text { size }\end{array}$ & M & $\begin{array}{c}\text { Sum of } \\
\text { Squares }\end{array}$ & df & $\begin{array}{c}\text { M } \\
\text { square }\end{array}$ & Sig. \\
\hline $\begin{array}{c}\text { Degree of promotional } \\
\text { effectiveness }\end{array}$ & 135 & 16.42 & 35.73 & 2 & 17.867 & .095 \\
\hline $\mathrm{*} p<0.05$ & & & & & & \\
\hline
\end{tabular}

According to the aforementioned statistical analysis results, this study discussed the comprehensive effectiveness of promoting energy education in elementary schools. The main points were as follows: (a) The $M$ scores of each dimension were greater than 3.9, demonstrating adequate promotional effectiveness. The promotional effectiveness is the greatest in the energy attitude dimension, whereas students exhibited weaker performance in energy knowledge and behaviors. This indicated that in response to energy-related problems, students often expressed their viewpoints, evaluated, acknowledged, and took action, thereby demonstrating greater sensitivity in energy awareness, energyrelated topics, and civic responsibilities. This was consistent with the results of other researches $[10,13,15]$. (b) The energy behavior dimension exhibited the lowest $M$ score across the three dimensions. This might result from the fact that behavior implementation requires a longer time. Fullan stated that the indirect aspect of promotional effectiveness are often visible after an extended period of time [16]. 
(c) Some Studies had found that the behavior attitude of primary school students is directly affected by the parents or social environment, behavior changes must start from an early age, change behavior must changing the awareness first, and in daily life to demonstrate, will be most effective [12-13].

Differences between areas in the effectiveness of energy education learning

According to the table 4, there is significant difference between urban areas and rural areas $(\mathrm{F}=14.23)$. The learning effectiveness of urban areas are higher than rural areas. This finding is consistent with of Zyadin, Puhakka, Ahponen, Cronberg, and Pelkonen [17]. However, it is inconsistent with the research of Rosalino et al. [10]. The result for this difference may be related to family education [12-13].

Table 4. Results analysis of the location of school dimensions

\begin{tabular}{|c|c|c|c|c|c|c|c|c|}
\hline \multirow{2}{*}{$\begin{array}{c}\text { location of } \\
\text { school }\end{array}$} & \multirow{2}{*}{$\begin{array}{l}\text { Number } \\
\text { of schools }\end{array}$} & \multirow[b]{2}{*}{$\mathbf{M}$} & \multirow[b]{2}{*}{ SD } & \multicolumn{5}{|c|}{ Variance analysis } \\
\hline & & & & $\begin{array}{l}\text { Source of } \\
\text { variation }\end{array}$ & SS & df & MS & $\mathbf{F}$ \\
\hline $\begin{array}{l}\text { Urban } \\
\text { areas }\end{array}$ & 28 & 51.9 & 5.09 & & & & & \\
\hline $\begin{array}{l}\text { Rural } \\
\text { areas }\end{array}$ & 17 & 44.8 & 7.61 & $\begin{array}{l}\text { location } \\
\text { of } \\
\text { school }\end{array}$ & 539.36 & 1 & 539.36 & $14.23 *$ \\
\hline & & & & total & 111393 & 45 & & \\
\hline
\end{tabular}

*p $<0.05$

\section{CONCLUSION AND SUGGESTION}

Based on the result and discussions, it can be concluded that the achievement of energy education was most effective in the "energy attitude", followed by "energy awareness" and "energy behavior". It shows that students have positive energy attitude, but they were relatively weak in energy saving behavior. The learning effectiveness of students in urban areas are higher than that in rural areas. Finally, we suggest that in addition to strengthen energy attitudes and energy awareness, we should encourage students to take action to save energy in their daily lives. Furthermore, we should invest more resources to rural areas to balance the students' performances between urban and rural areas.

\section{ACKNOWLEDGMENTS}

The study was funded by the Ministry of Science and Technology in Taiwan (MOST 105-2511-S-152009-MY3).

\section{REFERENCES}

[1] DeWaters, J. E., \& Powers, S. E. (2011). Energy literacy of secondary students in New York State (USA): A measure of knowledge, affect, and behavior. Energy policy, 39(3): 1699-1710.

[2] BBC News. (2018). Climate change: What next for saving the planet?. https://www.bbc.com/news/uk-scotland-

47746289?intlink_from_url=https://www.bbc.com/news/topics/cmj34zmwm1zt/climatechange\&link_location=live-reporting-story

[3] Mullis, I. V. S., Martin, M. O., Foy, P., \& Hooper, M. (2016). TIMSS 2015 International Results in Mathematics. Retrieved from Boston College, TIMSS \& PIRLS International Study Center website: http://timssandpirls.bc.edu/timss2015/international-results/

[4] Department of Energy's Office of Energy Efficiency and Renewable Energy (2019). Education Resources. https://www.energy.gov/eere/education/education-resources 
From Teachers' Views to Explore the Implementation of Energy Education in Taiwan's Elementary Schools Mei-Ching Chen, Chin-Cheng Chou, Chao-Ti Hsiung

[5] European Commission. (2019). Energy Strategy and Energy Union. https://ec.europa.eu/energy/en/topics/energy-strategy-and-energy-union

[6] Fullan, M. (2015). The new meaning of educational change (5nd ed.). New York: Teachers College Press.

[7] Mammadova, A. (2017). Sustainability Lessons from Kanazawa City, Japan. European Journal of Sustainable Development, 6(2): 233-233.

[8] Barrue, C., \& Albe, V. (2013). Citizenship education and socioscientific issues: Implicit concept of citizenship in the curriculum, views of French middle school teachers. Science \& Education, 22(5): 1089-1114.

[9] Thollander, P., Kimura, O., Wakabayashi, M., \& Rohdin, P. (2015). A review of industrial energy and climate policies in Japan and Sweden with emphasis towards SMEs. Renewable and Sustainable Energy Reviews, 50: 504-512.

[10] Rosalino, L. M., Gheler-Costa, C., Santos, G., Gonçalves, M. T., Fonseca, C., \& Leal, A. I. (2017). Conservation priorities for elementary school students: Neotropical and European perspectives. Biodiversity and conservation, 26(11): 2675-2697.

[11] Ministry of Education. (2017). Energy-Based National Science and Technology Talents Cultivation Program. http://old.energyedu.tw/intro.php

[12] Zorpas, A. A., Voukkali, I., \& Loizia, P. (2017). Effectiveness of waste prevention program in primary students' schools. Environmental Science and Pollution Research, 24(16): 14304-14311.

[13] Ando, K., Yorifuji, K., Ohnuma, S., Matthies, E., \& Kanbara, A. (2015). Transmitting proenvironmental behaviours to the next generation: A comparison between $\mathrm{G}$ ermany and $\mathrm{J}$ apan. Asian Journal of Social Psychology, 18(2): 134-144.

[14] Devellis, R. F. (1991). Scale development: Theory and applications. London: SAGE.

[15] Kok, G., Lo, S. H., Peters, G. J. Y., \& Ruiter, R. A. (2011). Changing energy-related behavior: An Intervention Mapping approach. Energy Policy, 39(9): 5280-5286.

[16] DeWaters, J., Powers, S., \& Graham, M. E. (2007). Developing an energy literacy scale. In ASEE Annual Conference and Exposition, Conference Proceedings.

[17] Zyadin, A., Puhakka, A., Ahponen, P., Cronberg, T., \& Pelkonen, P. (2012). School students' knowledge, perceptions, and attitudes toward renewable energy in Jordan. Renewable energy, 45: 78-85. 